\title{
Modification of Yield and Fiber Fractions Biosynthesis in Phaseolus vulgaris L. by Treatment with Biostimulants Containing Amino Acids and Seaweed Extract
}

\author{
Sławomir Kocira ${ }^{1, *(\mathbb{D}}$, Agnieszka Szparaga ${ }^{2}\left(\mathbb{D}\right.$, Pavol Findura ${ }^{3}$ and Krzysztof Treder ${ }^{4}(\mathbb{C}$ \\ 1 Department of Machinery Exploitation and Management of Production Processes, University of Life \\ Sciences in Lublin, Akademicka 13, 20-950 Lublin, Poland \\ 2 Department of Agrobiotechnology, Koszalin University of Technology, Racławicka 15-17, \\ 75-620 Koszalin, Poland; agnieszka.szparaga@tu.koszalin.pl \\ 3 Department of Machines and Production Biosystems, Slovak University of Agriculture in Nitra, \\ Tr. A. Hlinku 2, 94976 Nitra, Slovakia; pavol.findura@uniag.sk \\ 4 Laboratory of Molecular Diagnostic and Biochemistry, Bonin Research Center, Plant Breeding and \\ Acclimatization Institute-National Research Institute, 76-009 Bonin, Poland; k.treder@ihar.edu.pl \\ * Correspondence: slawomir.kocira@up.lublin.pl; Tel.: +48-815319735
}

Received: 29 July 2020; Accepted: 3 September 2020; Published: 5 September 2020

\begin{abstract}
The most serious of these is to stimulate the development of sustainable and, at the same time, environmentally friendly systems. Therefore, this study aimed to determine the effect of two biostimulants on the bean yield and fiber fractions in seeds: neutral-detergent fiber, acid-detergent fiber, lignin, cellulose, and hemicellulose. The field experiment performed in 2016-2018 in Poland. Over the growing season, plants were treated with biostimulants seaweed extracts (concentrations of $0.7 \%$ and $1 \%$ ) and amino acids $(0.3 \%$ and $0.5 \%$ ) based products. Plants were sprayed a single time in the Biologische Bundesanstalt, Bundessortenamt and Chemical industry $(\mathrm{BBCH}) 13-15$ phenological phases and a double spray in the $\mathrm{BBCH} 13-15$ and 61 . The study showed a significant increase in bean yield (average $32.08 \%$ compare to control) when seaweed extracts was used in the form of a double spray at a higher concentration. In the case of the application of amino acids-based product, the best results (increase of $21.97 \%$ ) were obtained using a double spray at a lower concentration. It was found that the tested biostimulants changed the fiber fractions of bean seeds. The acid-detergent fiber (ADF) content was the highest (average increase of $2 \%$ ) after double plant treatment with seaweed extracts based product. While the increased concentration of neutral-detergent fiber (NDF) (over $4 \%$ ) resulted from double spraying with lower concentration of this biostimulant. The increase in the lignin (ADL) $(1.12 \%)$, hemicellulose (HCEL) $(4.54 \%)$, and cellulose (CEL) (0.91\%) represented plant response to the double application of this biostimulant in the higher concentration. The results indicated also that the use of amino acids-based product caused an increase in the ADF $(0.28 \%)$, NDF $(10.27 \%)$, ADL $(0.63 \%)$, and HCEL $(9.99 \%)$ contents in bean seeds as an effect of double plant treatment with this biostimulant at lower concentration.
\end{abstract}

Keywords: biostimulant; neutral-detergent fiber; acid-detergent fiber; lignin; cellulose; hemicellulose; seed; yield

\section{Introduction}

Today, agriculture faces many challenges. The most serious of these is to stimulate the development of sustainable and, at the same time, environmentally friendly systems that will aid in feeding the 
growing world population. The global decline in arable land coupled with approaching the verge of plant genetic potential depletion set new goals for agriculture, related to the development of new methods (but not through genetic manipulation) that would allow increasing and protecting crop yields [1-5]. According to Eckardt et al. [6], agricultural production cannot rely only on increasing crop yields but also on improving their quality, especially in adverse environmental conditions. Only this comprehensive approach to the tasks of agriculture, while respecting the natural environment, will contribute to obtaining higher income for farmers, precisely because of the increase in yield and storage possibilities for crops. It will also allow the production of food of appropriate nutritional quality [7]. According to Kyriacou and Rouphael [8] the quality of crops "constitutes a dynamic composite of their physicochemical properties and consumer perception". Defining quality is an extremely difficult task, but the basis of efforts to improve and configure crop quality are the genotypic and agrienvironmental factors.

Currently, it seems that one of the most innovative and promising solutions for these important challenges is the use of plant biostimulants. Regulation (EU) 2019/1009 of the European Parliament and Council (EC) defines plant biostimulants as "EU fertilizing product able to stimulate plant nutrition processes independently of the product's nutrient content with the sole aim of improving one or more of the following characteristics of the plant or the plant rhizosphere: (1) nutrient use efficiency, (2) tolerance to abiotic stress, (3) quality traits, or (4) availability of confined nutrients in the soil or rhizosphere" [9].

On a global scale, the practical application of biostimulants in crop cultivation increases every year due to their potency to increase plant production. Godlewska and Ciepiela [10] explain this by the fact that this new agronomic practice allows reducing dependence on expensive mineral fertilizers and plant protection products, which additionally adversely affect the soil environment. In the literature, biostimulants have already gained the title of a new category of agricultural production means, improving the tolerance of plants to abiotic and biotic stress. The characteristics of their bioactive components, explanation of the mechanisms of their action, and evaluation of plant responses at various levels, including physiological, morphological, biochemical, and metabolomic ones, are currently in the focus of interest of many scientists from around the world. This scientific approach and knowledge resulting from ample studies (including those in real field conditions) allow for increasingly broad and conscious use of such products in agricultural practice [11].

The most commonly used biostimulants are based on humic compounds, amino acids, or seaweed extracts [12]. However, recent research also shows the biostimulatory potential of microalgae (eukaryotic and prokaryotic cyanobacteria). While it is known that microalgae produce bioactive compounds, their practical testing in crops has only just begun $[13,14]$. Many studies on the latter indicate that they can stimulate plant growth and development, increase photosynthetic activity and resistance to fungi, bacteria, and viruses, and tolerance to adverse environmental conditions, thereby improving the yield and productivity of many crops [15-19]. This is because the seaweed-based biostimulants contain cytokinins, auxins, or other hormone-like substances [20]. Plant growth stimulation and increased plant resistance to stress have also been reported after using biostimulants containing protein hydrolysates and free amino acids. Some research results indicate that the positive effect on plant growth and development may be due to the nutritional effect of an additional nitrogen source [21]. The conclusions of such studies indicate that plants can readily absorb amino acids and peptides contained in biostimulants, and this in turn, in adverse environmental conditions, leads to the induction of several plant defense reactions, by increasing plant tolerance to salinity, drought, and reduced or elevated temperature $[19,22-28]$.

Bean grown for dry seeds is widely recognized and used because of their nutritional value, mainly due to their protein content. Bean seeds contain approximately $90 \%$ dry matter, including approximately $60 \%$ carbohydrates (mainly starch-approximately $40 \%$ and dietary fiber-approximately 16\%), approximately $22 \%$ protein, and mineral salts [29]. 
In terms of carbohydrate content, $100 \mathrm{~g}$ of raw bean seeds contain $52-76 \mathrm{~g}$ of these essential components. Starch is the major carbohydrate fraction [30], but bean seeds also contain slowly digestible carbohydrates and a high percentage of non-digestible carbohydrates that can be fermented in the human large intestine. These non-digestible sugars include, among others, resistant starch, soluble and insoluble dietary fiber, and non-digestible oligosaccharides [31]. However, many literature works emphasize the high content of dietary fiber in bean seeds (two to three times higher per $100 \mathrm{~g}$ of the edible portion than in other basic foodstuffs), whose main constituents include pectins, pentosans, hemicellulose, cellulose, and lignin [30,32,33]. The American Association of Cereal Chemists (AACC) defined the concept of dietary fiber as "an edible part of plants or analogously carbohydrates resistant to digestion and absorption in the small intestine, which are fully or partially fermented in the large intestine" [34]. Dietary fiber plays a crucial role in developing food structure, carbohydrate availability, and, thus, in the glycemic index of food [33].

In addition, bean seeds are classified as functional foods because they contain bioactive phytochemicals such as polyphenols, tannins, and fiber fractions [35-37]. However, according to Chávez-Mendoza and Sánchez [33], such a favorable chemical composition of bean seeds does not currently translate into their increased consumption. Numerous studies emphasize the need to promote such products in human nutrition in response to the increased incidence of chronic diseases, including cancer, obesity, and cardiovascular diseases [38]. Today, growing scientific evidence indicates the essential role of bioactive compounds, the fiber in particular, in the prevention and treatment of diseases, due to their beneficial effect on health [33,39].

Considering the above, it becomes justified to use biostimulants in the cultivation of bean, which represents plants nutritionally valuable but sensitive to fluctuating environmental conditions (has high thermal and light requirements), which, by causing stress reactions, lead to reduced yield in field conditions. According to Karr-Lilienthal et al. [40], fiber composition may be influenced by plant cultivar as well as growing conditions, including soil type, fertilizer or biostimulant application, and climatic conditions such as drought and/or rainy weather. Joubert and Lefranc [41] also proved that the active ingredients of biostimulants based on seaweed extracts and amino acids exhibit the activity of phytoactivators, whose action may consist in modifying the chemical composition of treated plants, including their fiber content.

This study was undertaken to test the hypothesis that the use of biostimulants based on amino acids and seaweed extracts can not only improve bean yield but also affect the content of bioactive compounds in bean seeds. Therefore, this study aimed to determine the effect of two biostimulants in the yield of bean, as well as on selected components and metabolic parameters of the yield (fiber fractions in seeds, including neutral-detergent fiber, acid-detergent fiber, lignin, cellulose, and hemicellulose).

\section{Materials and Methods}

\subsection{Plant Materials and Growth Conditions}

A field experiment was performed in the years 2016-2018 in Perespa village (50 $66^{\prime} \mathrm{N} ; 23^{\circ} 63^{\prime} \mathrm{E}$, Poland) with common bean (Phaseolus vulgaris L.) of Mexican Black cultivar. The experiment was established in a random block design, in 4 replications, on experimental plots with the surface area of $10 \mathrm{~m}^{2}$. Bean was cultivated on the soil belonging to the Gleyic Phaeozems, which was characterized by an alkaline $\mathrm{pH}$ ( $\mathrm{pH}$ in $1 \mathrm{M} \mathrm{KCl}$ : 7.4-7.5). Contents of available nutrients in the soil were at medium levels: P (5.5-6.2 mg P in $100 \mathrm{~g}$ of soil), K (12.7-14.3 mg K in $100 \mathrm{~g}$ of soil), $\mathrm{Mg}$ (6.2-6.8 mg Mg in $100 \mathrm{~g}$ of soil), and $\mathrm{N}\left(8.1-9.3 \mathrm{mg} \mathrm{N}-\mathrm{NO}_{3}+\mathrm{N}-\mathrm{NH}_{4}\right.$ in $100 \mathrm{~g}$ of soil). Bean seeds were sown on the 2 May, 2016, 2017, and 2018, with $3.5 \mathrm{~cm}$ gaps in rows with $45 \mathrm{~cm}$ spacing. No herbicides were used, and weeds were removed mechanically and manually. In particular growing seasons, bean plants were sprayed with Kelpak SL (seaweed extracts - based product) and Terra Sorb Complex (amino acids-based product) biostimulants, according to the scheme presented in Table 1. Plants sprayed with water (being a solvent to the biostimulants used) served as the control. 
In Biologische Bundesanstalt, Bundessortenamt and Chemical industry (BBCH) 89, after the pods maturation, plants were collected from each plot for analysis (20 plants per experimental unit).

Biostimulants were used in terms when the foliar application of microelements is recommended. Their doses were established based on the authors' experience from previous investigations [42,43].

Table 1. Plant developmental stages and dates of biostimulant application.

\begin{tabular}{|c|c|c|c|c|}
\hline 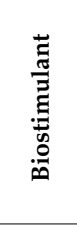 & Biostimulant Composition $[17,28]$ & $\begin{array}{c}\text { Number of Sprays } \\
\text { and Plant } \\
\text { Developmental } \\
\text { Stages (BBCH) in } \\
\text { which the } \\
\text { Biostimulants Were } \\
\text { Applied }\end{array}$ & 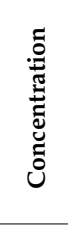 & $\begin{array}{c}\text { Volume of Working } \\
\text { Solution/Working } \\
\text { Pressure }\end{array}$ \\
\hline \multirow{4}{*}{ 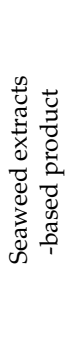 } & \multirow{4}{*}{ 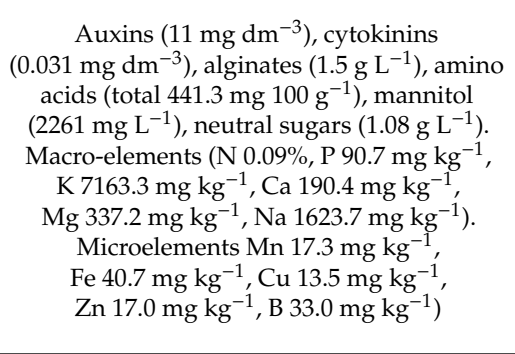 } & $\begin{array}{l}\text { Single spraying: } \\
\text { BBCH 13-15 (LSS) }\end{array}$ & $0.7 \%$ & \multirow{4}{*}{$\begin{array}{c}300 \mathrm{~L} \cdot \mathrm{ha}^{-1} / \\
0.30 \mathrm{MPa}\end{array}$} \\
\hline & & $\begin{array}{l}\text { Single spraying: } \\
\text { BBCH 13-15 (HSS) }\end{array}$ & $1.0 \%$ & \\
\hline & & $\begin{array}{c}\text { Double spraying: } \\
\text { BBCH 13-15, BBCH } \\
61 \text { (LDS) }\end{array}$ & $0.7 \%$ & \\
\hline & & $\begin{array}{c}\text { Double spraying: } \\
\text { BBCH 13-15, BBCH } \\
61 \text { (HDS) }\end{array}$ & $1.0 \%$ & \\
\hline \multirow{4}{*}{ 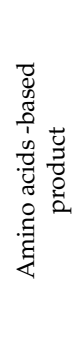 } & \multirow{4}{*}{$\begin{array}{c}\text { Aliphatic amino acids (glycine, alanine, } \\
\text { valine, leucine, isoleucine, proline). } \\
\text { Hydroxy-amino acids (serine, threonine). } \\
\text { S-containing amino acids (cysteine, } \\
\text { methionine). Aromatic amino acids } \\
\text { (phenylalanine, tryptophan, tyrosine). Acidic } \\
\text { amino acids (aspartic acid, glutamic acid). } \\
\text { Basic amino acids (histidine, arginine, lysine). } \\
\text { Organic } \mathrm{N}(5.0 \%), \mathrm{B}(1.5 \%), \mathrm{Mg}(0.8 \%), \\
\mathrm{Fe}(1 \%), \mathrm{Zn}(0.1 \%), \mathrm{Mn}(0.1 \%), \mathrm{Mo}(0.001 \%), \\
\text { and many micro-elements }\end{array}$} & $\begin{array}{l}\text { Single spraying: } \\
\text { BBCH 13-15 (LSS) }\end{array}$ & $0.3 \%$ & \multirow{4}{*}{$\begin{array}{c}300 \mathrm{~L} \cdot \mathrm{ha}^{-1} / \\
0.30 \mathrm{MPa}\end{array}$} \\
\hline & & $\begin{array}{c}\text { Single spraying: } \\
\text { BBCH 13-15 (HSS) }\end{array}$ & $0.5 \%$ & \\
\hline & & $\begin{array}{c}\text { Double spraying: } \\
\text { BBCH 13-15, BBCH } \\
61 \text { (LDS) }\end{array}$ & $0.3 \%$ & \\
\hline & & $\begin{array}{c}\text { Double spraying: } \\
\text { BBCH 13-15, BBCH } \\
61 \text { (HDS) }\end{array}$ & $0.5 \%$ & \\
\hline
\end{tabular}

$\mathrm{BBCH}-$ Biologische Bundesanstalt, Bundessortenamt and Chemical industry; $\mathrm{BBCH}$ 13-15-3 leaves unfolded. $\mathrm{BBCH}$ 61-beginning of flowering: approximately $10 \%$ of flowers open. LSS, lower concentration single spraying; HSS, higher concentration single spraying; LDS, lower concentration double spraying; HDS, higher concentration double spraying.

Average temperatures and rainfall in three growing seasons of bean are presented in Table 2. The meteorological data for the field experiment come from weather station (W200P, Vector Instruments Ltd., Rhyl, UK) was located in the experimental field, in which the experiment was carried out, at $210 \mathrm{~m}$ above sea level.

Table 2. Temperature (T) and rainfall in growing seasons 2016-2018.

\begin{tabular}{|c|c|c|c|c|c|c|c|c|}
\hline \multirow{3}{*}{ Month } & \multicolumn{6}{|c|}{ Year } & \multirow{2}{*}{\multicolumn{2}{|c|}{$\begin{array}{l}\text { Average from } 2002 \\
\text { to } 2015\end{array}$}} \\
\hline & \multicolumn{2}{|c|}{2016} & \multicolumn{2}{|c|}{2017} & \multicolumn{2}{|c|}{2018} & & \\
\hline & $\begin{array}{c}\mathrm{T}\left({ }^{\circ} \mathrm{C}\right) \\
\text { Average } \\
(\mathrm{min} / \mathrm{max})\end{array}$ & $\begin{array}{l}\text { Rainfall } \\
(\mathrm{mm})\end{array}$ & $\begin{array}{c}\text { T }\left({ }^{\circ} \mathrm{C}\right) \\
\text { Average } \\
(\mathrm{min} / \mathrm{max})\end{array}$ & $\begin{array}{l}\text { Rainfall } \\
(\mathrm{mm})\end{array}$ & $\begin{array}{c}\mathrm{T}\left({ }^{\circ} \mathrm{C}\right) \\
\text { Average } \\
\text { (min/max) }\end{array}$ & $\begin{array}{l}\text { Rainfall } \\
(\mathrm{mm})\end{array}$ & $\mathrm{T}\left({ }^{\circ} \mathrm{C}\right)$ & $\begin{array}{l}\text { Rainfall } \\
\text { (mm) }\end{array}$ \\
\hline IV & $\begin{array}{c}9.2 \\
(-1.2 / 22.6)\end{array}$ & 68.4 & $\begin{array}{c}7.7 \\
(-1.6 / 23.3)\end{array}$ & 37.2 & $\begin{array}{c}11.5 \\
(-1.0 / 23.1)\end{array}$ & 29.6 & 8.6 & 41.9 \\
\hline V & $\begin{array}{c}13.8 \\
(2.6 / 26.7)\end{array}$ & 61.3 & $\begin{array}{c}13.7 \\
(-1.4 / 26.9)\end{array}$ & 100.0 & $\begin{array}{c}14.2 \\
(1.9 / 25.8)\end{array}$ & 54.7 & 12.6 & 64.1 \\
\hline VI & $\begin{array}{c}18.1 \\
(4.2 / 31.5)\end{array}$ & 97.1 & $\begin{array}{c}18.3 \\
(5.7 / 30.2)\end{array}$ & 38.6 & $\begin{array}{c}18.0 \\
(5.2 / 30.6)\end{array}$ & 77.1 & 17.8 & 68.3 \\
\hline VII & $\begin{array}{c}19.5 \\
(8.8 / 31.2)\end{array}$ & 107.6 & $\begin{array}{c}18.5 \\
(5.3 / 32.9)\end{array}$ & 61.1 & $\begin{array}{c}19.1 \\
(7.6 / 32.4)\end{array}$ & 93.7 & 18.8 & 79.4 \\
\hline VIII & $\begin{array}{c}18.2 \\
(7.1 / 30.7)\end{array}$ & 95.3 & $\begin{array}{c}19.5 \\
(4.3 / 34.4)\end{array}$ & 25.5 & $\begin{array}{c}19.8 \\
(6.3 / 31.9)\end{array}$ & 64.5 & 19.5 & 71.5 \\
\hline IX & $\begin{array}{c}15.2 \\
(1.6 / 28.7)\end{array}$ & 41.2 & $\begin{array}{c}13.2 \\
(-0.3 / 27.3)\end{array}$ & 100.4 & $\begin{array}{c}15.1 \\
(1.9 / 26.9)\end{array}$ & 44.3 & 14.0 & 69.6 \\
\hline Average/Total & 17.1 & 470.9 & 15.2 & 362.8 & 16.3 & 363.9 & 15.2 & 394.8 \\
\hline
\end{tabular}




\subsection{Plant Yielding}

Determinations were conducted for: pod number per $1 \mathrm{~m}^{2}$, seed number per $1 \mathrm{~m}^{2}$, seed weight per $1 \mathrm{~m}^{2}$, and thousand seed weight.

\subsection{Dietary Fiber Analysis}

Ground bean seeds were determined for contents of the following dietary fiber fractions: neutral-detergent fiber (NDF), acid-detergent fiber (ADF), and lignin (ADL). Determinations were conducted in three replications, according to the Van Soest et al. [44] method using filtration bags and Ankom apparatus (Ankom220, Macedon, NY, USA). The NDF content was evaluated using a solution of neutral detergent (sodium-lauryl sulfate, ethylenediamine tetra acetic disodium salt, sodium borate, di-basic sodium phosphate, and triethylene glycol), alpha-amylase (17,400 liquid units/mL, FAA Ankom Technology, Macedon, NY, USA), and sodium sulfite (FSS Ankom Technology). The ADF content was determined using an acid detergent (trimethylammonium bromide, standardized sulfuric (VI) acid). After examining the ADF content, the lignin content was assayed in bean samples using a standardized solution of sulfuric (VI) acid (Ankom Technology, FSA 72). The difference between the contents of NDF and ADF fractions was used to compute the hemicellulose (HCEL) concentration, and the difference between the contents of ADF and lignin (ADL) served to calculate the cellulose (CEL) concentration in bean samples.

\subsection{Statistical Analysis}

Analyses were performed in three replications for each growing season. The Shapiro-Wilk test was used to evaluate the normal distribution of data. Results were analyzed using the one-way analysis of variance (ANOVA). The significance of differences between mean values was estimated based on Tukey confidence intervals, at a significance level of $p<0.05$. The statistical analysis was performed using Statistica 13.3 software (TIBCO Software Inc., Palo Alto, CA, USA).

\section{Results}

The foliar application of biostimulants based on seaweed and amino acids in the cultivation of common bean of Mexican Black cultivar modified the biometric traits and the yield of seeds (Table 3). In all of the study years, the double application of Kelpak preparation in the higher concentration caused increase of thousand seed weight compared to the control and the other combinations. In 2016, the application of Terra Sorb Complex preparation had a negative effect on thousand seed weight, whereas in 2017 and 2018 its double application in the higher concentration decreased its value compared to the control and the other combinations.

Table 3. Effect of biostimulant treatment on the biometric traits of bean.

\begin{tabular}{|c|c|c|c|c|c|c|c|c|c|}
\hline \multirow{4}{*}{ Parameters } & \multirow{4}{*}{ 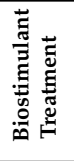 } & \multicolumn{8}{|c|}{ Biostimulant } \\
\hline & & \multicolumn{4}{|c|}{ Kelpak SL } & \multicolumn{4}{|c|}{ Terra Sorb Complex } \\
\hline & & \multicolumn{3}{|c|}{ Season } & \multirow{2}{*}{ Average } & \multicolumn{3}{|c|}{ Season } & \multirow{2}{*}{ Averag } \\
\hline & & 2016 & 2017 & 2018 & & 2016 & 2017 & 2018 & \\
\hline \multirow{5}{*}{$\begin{array}{l}1000 \text { seed weight } \\
\left({\left.\mathrm{g} 1000^{-1}\right)}^{-1}\right.\end{array}$} & $\mathrm{C}$ & $177.1 \mathrm{bA}$ & $152.8 \mathrm{aB}$ & $151.7 \mathrm{abB}$ & $160.5 \mathrm{a}$ & $177.1 \mathrm{aA}$ & $152.8 \mathrm{aB}$ & $151.7 \mathrm{aB}$ & $160.5 \mathrm{a}$ \\
\hline & LSS & $167.2 \mathrm{cdA}$ & $148.9 \mathrm{abC}$ & $156.4 \mathrm{aB}$ & $157.5 \mathrm{a}$ & $167.2 \mathrm{cbA}$ & $155.4 \mathrm{aA}$ & 154.9 aA & $159.2 \mathrm{a}$ \\
\hline & HSS & $166.5 \mathrm{dA}$ & $138.4 \mathrm{bA}$ & $138.0 \mathrm{bA}$ & $147.6 \mathrm{a}$ & $159.3 \mathrm{cA}$ & $158.5 \mathrm{aA}$ & $147.7 \mathrm{aA}$ & $155.2 \mathrm{a}$ \\
\hline & LDS & $172.2 \mathrm{bA}$ & $147.0 \mathrm{abB}$ & $158.6 \mathrm{aB}$ & $159.3 \mathrm{a}$ & $171.9 \mathrm{abA}$ & $153.6 \mathrm{aB}$ & $152.5 \mathrm{aB}$ & $159.3 \mathrm{a}$ \\
\hline & HDS & $182.8 \mathrm{aA}$ & $155.7 \mathrm{aB}$ & $159.3 \mathrm{aB}$ & $165.9 \mathrm{a}$ & $168.7 \mathrm{bA}$ & $137.0 \mathrm{bB}$ & $137.1 \mathrm{bB}$ & $147.6 \mathrm{a}$ \\
\hline \multirow{5}{*}{$\begin{array}{l}\text { Seed yield } \\
\left(\mathrm{g} \mathrm{m}^{-2}\right)\end{array}$} & $\mathrm{C}$ & 247.9 cC & $278.4 \mathrm{~dB}$ & $316.2 \mathrm{cA}$ & $280.8 \mathrm{~b}$ & $247.9 \mathrm{c}$ & $278.4 \mathrm{c}$ & $316.2 \mathrm{c}$ & $280.8 \mathrm{a}$ \\
\hline & LSS & $320.3 \mathrm{bB}$ & $359.9 \mathrm{abB}$ & $393.9 \mathrm{abAB}$ & $358.0 \mathrm{a}$ & $258.0 \mathrm{bB}$ & $329.8 \mathrm{bA}$ & $340.8 \mathrm{bA}$ & $309.5 \mathrm{a}$ \\
\hline & HSS & $322.5 \mathrm{bA}$ & $319.2 \mathrm{cA}$ & $334.3 \mathrm{bcA}$ & $325.3 \mathrm{a}$ & $266.7 \mathrm{bB}$ & $393.6 \mathrm{aA}$ & $358.2 \mathrm{abA}$ & $339.5 \mathrm{a}$ \\
\hline & LDS & $330.2 \mathrm{abB}$ & $330.7 \mathrm{bcB}$ & $411.9 \mathrm{aA}$ & $357.6 \mathrm{a}$ & $284.1 \mathrm{aB}$ & $381.1 \mathrm{aA}$ & $362.4 \mathrm{aA}$ & $342.5 \mathrm{a}$ \\
\hline & HDS & $338.6 \mathrm{aA}$ & $370.1 \mathrm{aA}$ & $403.9 \mathrm{aA}$ & $370.9 \mathrm{a}$ & $257.8 \mathrm{bB}$ & $334.5 \mathrm{bA}$ & $340.6 \mathrm{bA}$ & $311.0 \mathrm{a}$ \\
\hline \multirow{5}{*}{$\begin{array}{l}\text { Number of pods } \\
\quad\left(\text { per } \mathrm{m}^{-2}\right)\end{array}$} & $\mathrm{C}$ & $349 \mathrm{~dB}$ & $421 \mathrm{cA}$ & $427 \mathrm{cA}$ & $399 \mathrm{~b}$ & $349 \mathrm{cB}$ & $421 \mathrm{cA}$ & $427 \mathrm{cA}$ & $399 \mathrm{~b}$ \\
\hline & LSS & $490 \mathrm{cA}$ & $600 \mathrm{aA}$ & $627 \mathrm{aA}$ & $572 \mathrm{a}$ & $494 \mathrm{bA}$ & $483 \mathrm{cA}$ & $505 \mathrm{bA}$ & $494 \mathrm{ab}$ \\
\hline & HSS & $576 \mathrm{bA}$ & $584 \mathrm{aA}$ & $587 \mathrm{abA}$ & $582 \mathrm{a}$ & $517 \mathrm{abB}$ & $663 \mathrm{aA}$ & $655 \mathrm{aA}$ & $612 \mathrm{a}$ \\
\hline & LDS & $654 \mathrm{dA}$ & $491 \mathrm{bA}$ & $585 \mathrm{abA}$ & $577 \mathrm{a}$ & $515 \mathrm{abB}$ & $704 \mathrm{aA}$ & $690 \mathrm{aA}$ & $636 a$ \\
\hline & HDS & $551 \mathrm{bA}$ & $556 \mathrm{aA}$ & $557 \mathrm{bA}$ & $555 a$ & $520 \mathrm{aA}$ & $578 \mathrm{bA}$ & $567 \mathrm{aA}$ & $555 \mathrm{ab}$ \\
\hline
\end{tabular}


Table 3. Cont.

\begin{tabular}{|c|c|c|c|c|c|c|c|c|c|}
\hline \multirow{4}{*}{ Parameters } & \multirow{4}{*}{ 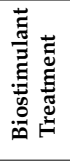 } & \multicolumn{8}{|c|}{ Biostimulant } \\
\hline & & \multicolumn{4}{|c|}{ Kelpak SL } & \multicolumn{4}{|c|}{ Terra Sorb Complex } \\
\hline & & \multicolumn{3}{|c|}{ Season } & \multirow{2}{*}{ Average } & \multicolumn{3}{|c|}{ Season } & \multirow{2}{*}{ Average } \\
\hline & & 2016 & 2017 & 2018 & & 2016 & 2017 & 2018 & \\
\hline \multirow{5}{*}{$\begin{array}{l}\text { Number of seeds } \\
\quad\left(\text { per } \mathrm{m}^{-2}\right)\end{array}$} & $\mathrm{C}$ & $1399 \mathrm{cB}$ & $1822 \mathrm{dA}$ & $2084 \mathrm{bA}$ & $1768 \mathrm{a}$ & $1399 \mathrm{cB}$ & $1822 \mathrm{cA}$ & $2084 \mathrm{cA}$ & 1768 a \\
\hline & LSS & $1915 \mathrm{aB}$ & $2415 \mathrm{aA}$ & $2518 \mathrm{aA}$ & $2283 \mathrm{a}$ & $1543 \mathrm{bB}$ & $1969 \mathrm{cA}$ & $2050 \mathrm{cA}$ & 1854 a \\
\hline & HSS & $1937 \mathrm{aB}$ & $2308 \mathrm{bcA}$ & $2425 \mathrm{aA}$ & $2223 \mathrm{a}$ & $1675 \mathrm{aB}$ & $2799 \mathrm{bA}$ & $2815 \mathrm{bA}$ & $2430 \mathrm{a}$ \\
\hline & LDS & $1917 \mathrm{aC}$ & 2248 cB & 2588 aA & $2251 \mathrm{a}$ & $1652 \mathrm{aB}$ & 2985 aA & 2992 aA & $2543 a$ \\
\hline & HDS & $1852 \mathrm{bB}$ & $2376 \mathrm{abA}$ & 2535 aA & $2254 \mathrm{a}$ & $1528 \mathrm{bB}$ & $2740 \mathrm{bA}$ & $2830 \mathrm{bA}$ & 2366 a \\
\hline
\end{tabular}

Abbreviations: C—control; LSS-lower concentration single spraying; LDS-lower concentration double spraying; HSS-higher concentration single spraying; HDS-higher concentration double spraying. Means in the columns, followed by different small letters are significantly different at $p<0.05$ (effect of biostimulant treatment). Means in the rows, followed by different big letters are significantly different at $p<0.05$ (effect of season).

In each study year, the foliar application of Kelpak SL and Terra Sorb Complex significantly increased bean seed yield compared to the control treatment. In the case of Kelpak SL, the most beneficial appeared to be its double application in the higher concentration. In turn, in the case of Terra Sorb Complex, the best effects were achieved upon double plant spraying with it at its lower concentration. The seed yield increase was due to the positive plant response to the treatment with these biostimulants that was reflected in an increased pod number, and seed number compared to the control combination.

Application of Terra Sorb Complex generally contributed to a decreased content of acid-detergent fiber in bean seeds compared to the control treatment (Figure 1). A value similar to that determined for the control seeds was obtained only after double plant spraying with this preparation in its lower concentration (average 2016-2018). The foliar application of Terra Sorb Complex biostimulant in common bean cultivation caused significantly changes in ADF content in seeds in each growing season. In 2016 and 2017, the double plant treatment with this biostimulant in its higher concentration, was more effective in increasing the ADF content of bean seeds compared to the other tested treatments. On the other hand in the third growing season, an increase in ADF after the use of Terra Sorb Complex was the highest after double plant treatment with working solutions in the lower concentrations.

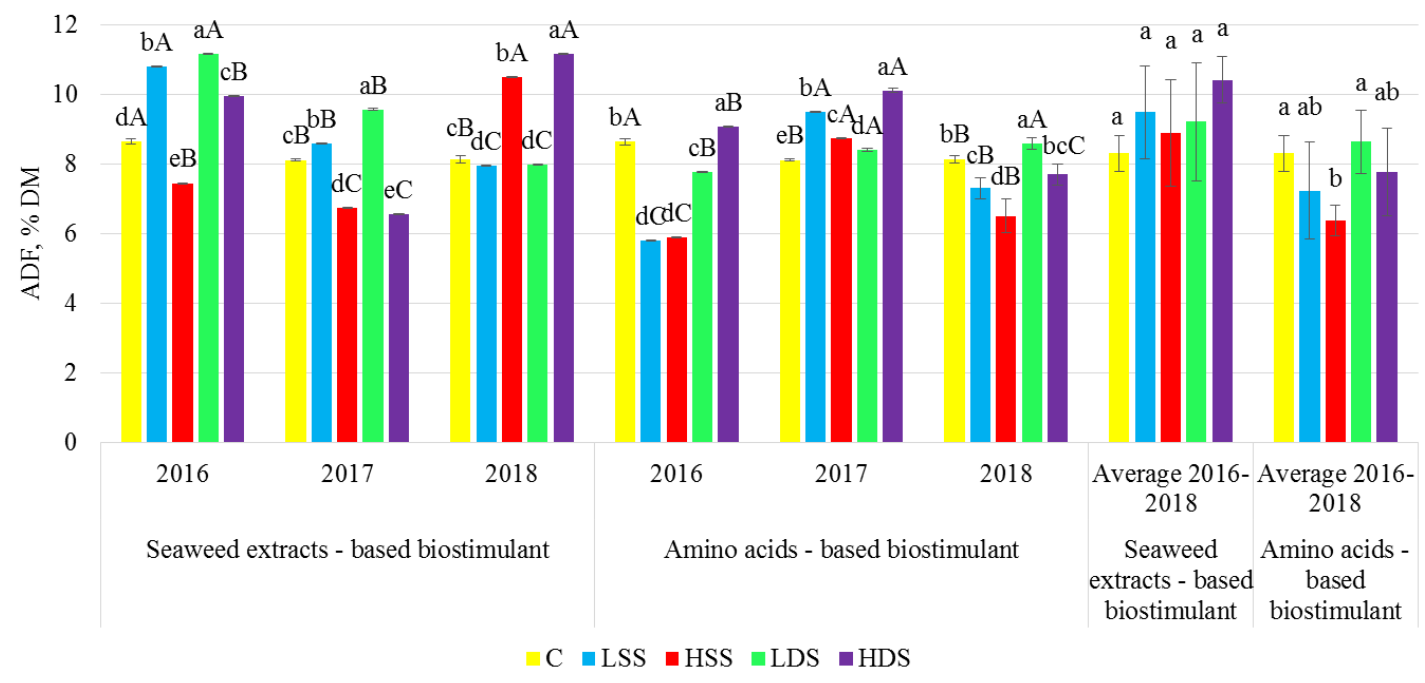

Figure 1. Effect of biostimulants treatment on the acid-detergent fiber (ADF) content in common bean seeds. Abbreviations: C, control; LSS, lower concentration single spraying; LDS, lower concentration double spraying; HSS higher concentration single spraying; HDS, higher concentration double spraying. Means followed by different small letters are significantly different at $p<0.05$ (effect of biostimulant treatment). Means, followed by different big letters are significantly different at $p<0.05$ (effect of season). 
Opposite observations were made for Kelpak SL biostimulant which caused an increase in ADF content in seeds from all combinations compared to the control seeds (Figure 1, average 2016-2018). The greatest increase in ADF content was determined in the seeds from plants double-sprayed with this biostimulant in the higher concentration, i.e., $1 \%$. The analysis of growing seasons demonstrated the highest value of ADF in 2016 and 2018. The greatest increase in ADF content of bean seeds was due to the double plant treatment with Kelpak SL in its lower (2016) and higher concentration (2018). Meteorological conditions of the growing season of 2016 had a more beneficial effect on the content of this fiber fraction, as they ensured the highest ADF content in bean seeds compared to the other study years. In 2016, during the growing season, occurred favorable water conditions, resulting from even rainfall. In the last month, the amount of rainfall was the lowest, which had a positive effect on the quality of seeds. In 2016, compared to the other two years, the highest average temperature was recorded (Table 2). The application of Kelpak SL increased significantly this value. In turn, in 2017 the ADF content determined in bean seeds was lower than in the other study years. The increase in the ADF content of bean seeds in the second year of the experiment, represented plant response to the double application of this biostimulant in the lower concentration.

Considering the detergent-neutral fraction of dietary fiber, its content in bean seeds was found to depend on biostimulant type (Figure 2). The use of Kelpak SL preparation resulted in NDF content increase compared to the control seeds, regardless of the number of its applications and its concentration (the differences observed in NDF content of bean seeds were statistically insignificant for the average 2016-2018). The greatest increase was determined after double plant spraying with this biostimulant in its higher concentration.

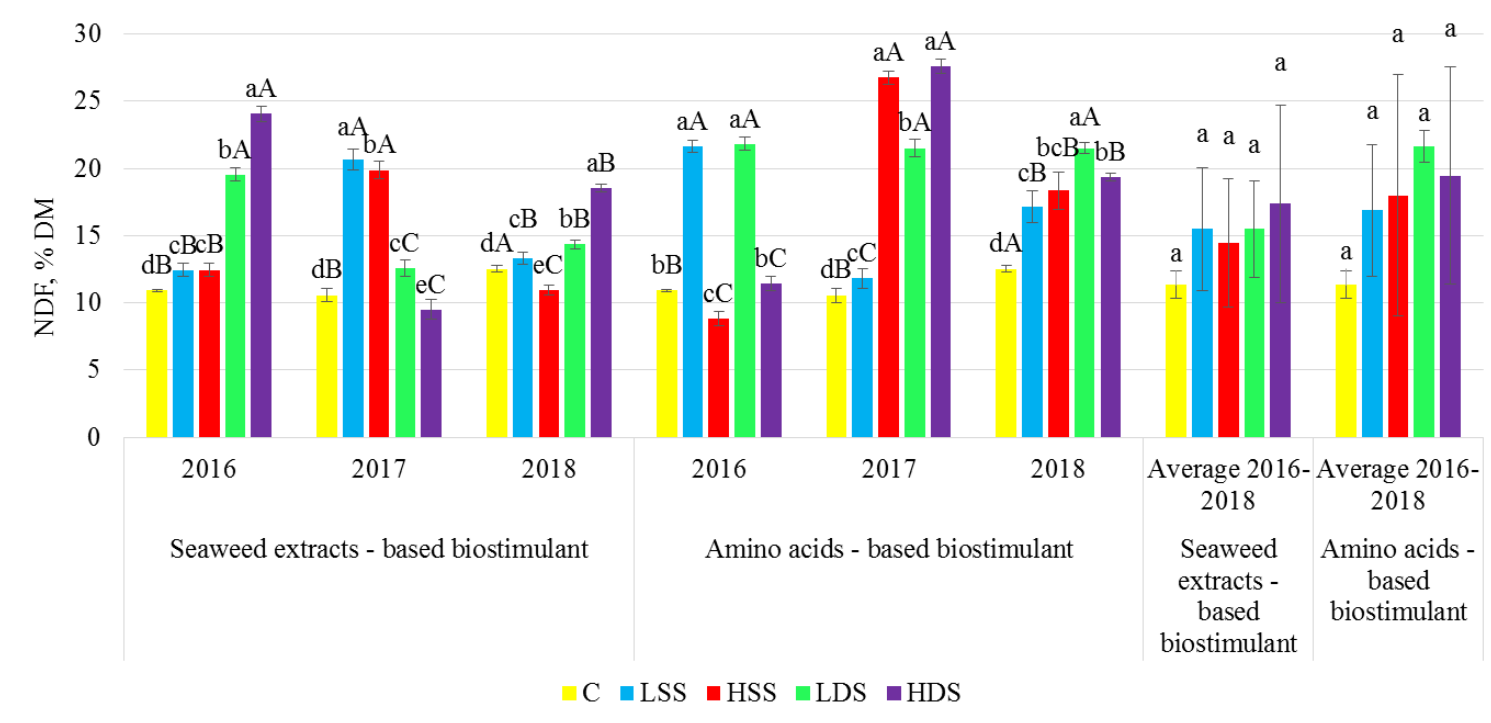

Figure 2. Effect of biostimulants treatment on the neutral-detergent fiber (NDF) content in common bean seeds. Abbreviations: C—control; LSS-lower concentration single spraying; LDS-lower concentration double spraying; HSS - higher concentration single spraying; HDS—higher concentration double spraying. Means followed by different small letters are significantly different at $p<0.05$ (effect of biostimulant treatment). Means, followed by different big letters are significantly different at $p<0.05$ (effect of season).

The content of neutral-detergent fiber in bean seeds was the highest in 2016. In the case of Kelpak SL preparations, the neutral-detergent fiber content determined after double application of their higher concentrations, was higher than in the other study years. As in the case of NDF analysis in 2018, bean plants respond to Kelpak SL treatment with a change in neutral-detergent fiber content similar to the first year of the experiment. An opposite observation was made after the use of Kelpak SL in 2017, where the content of NDF increased after single foliar application of $0.7 \%$ Kelpak SL solution. 
When analyzing the three-year averages, it was observed that double bean plant treatment with Terra Sorb Complex contributed to an increase in NDF fraction content in bean seeds compared to the control treatment, with the greatest increase observed upon the use of the biostimulant in the lower concentration (LDS). The greatest increase in neutral-detergent fiber content of bean seeds was noted 2017, due to the double plant treatment with Terra Sorb Complex in both tested concentration. In 2016, the NDF content determined in seeds was higher after both form of biostimulant spraying with lower concentration of working solutions. In the third year of the experiment a highest increase in the NDF content of bean seeds represented plant response to the double application of Terra Sorb Complex in the lower concentration.

The analysis of the bean response to the Terra Sorb Complex biostimulant showed a significantly increase in the content of lignin only in the seeds of the plant twice sprayed with this preparation at a lower concentration compared to the control seeds (Figure 3). This trend in the obtained results was observed in each year of the field experiment. In the other combinations, ADL contents were not higher than in the control samples. A significant decrease in ADL content (average 2016-2018) was determined after single application of this preparation in the higher concentration (HSS). When analyzing the three-year averages, it was observed an opposite tendency was observed for the combinations with Kelpak SL. In their case, ADL content increased compared to the control seeds in all combinations tested, and the magnitude of the increase was found to depend on the number of applications and concentration of biostimulant. The greatest increase in lignin content was determined after use Kelpak $\mathrm{SL}$ in the form of double spraying in higher concentration. Statistical analysis of the three-year averages, however, did not reveal any significant differences in ADL content compared to the control combination (Figure 3). Additionally, the detailed analysis of the results from the three-year experiment showed that there were significant differences in ADL content between control samples and plants treated with Kelpak SL preparation in each growing season. A significant increase in ADL content was determined in 2017 and 2016 after double foliar application of Kelpak SL, respectively, in the higher and lower concentration. Whereas, in 2018, the highest lignin content in seeds was noted after single treatment of bean plants by this biostimulant in lower concentration of working solution.

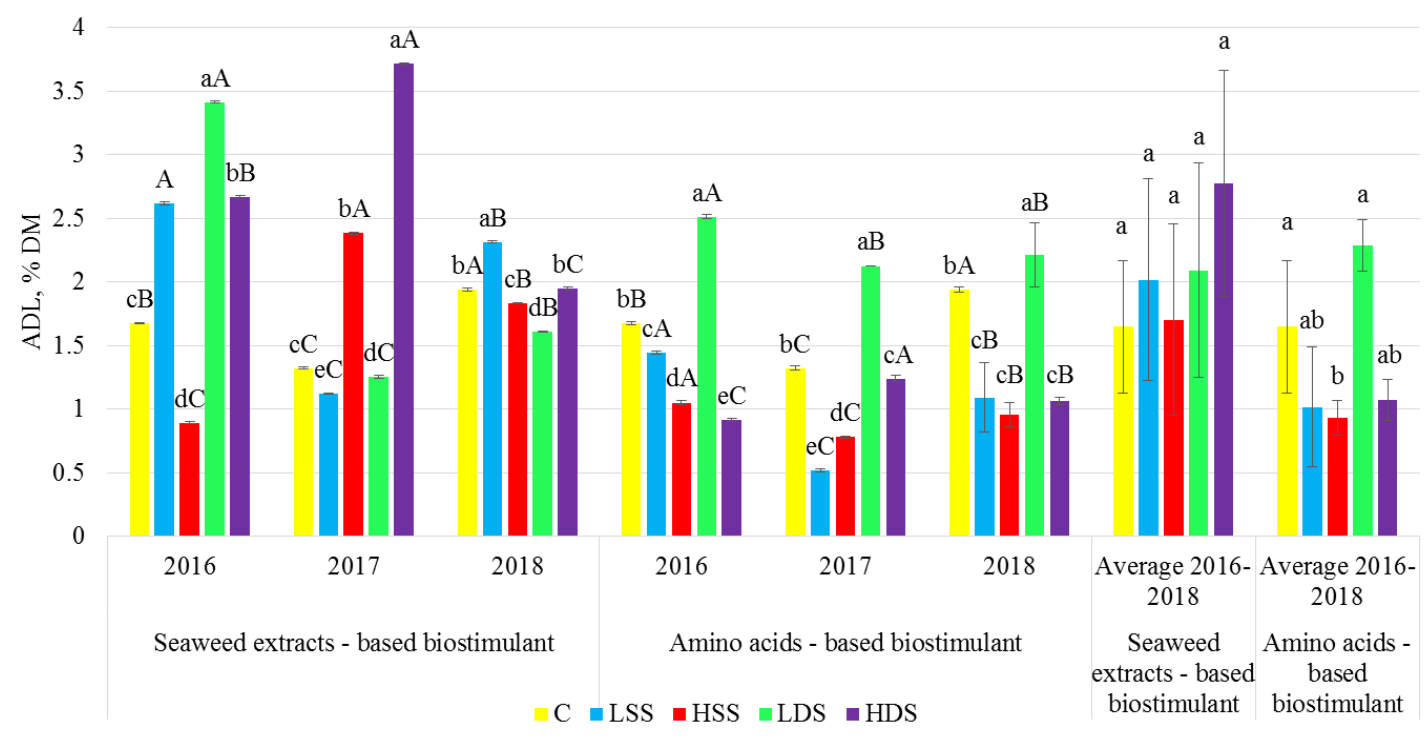

Figure 3. Effect of biostimulants treatment on the lignin (ADL) content in common bean seeds. Abbreviations: C-control; LSS-lower concentration single spraying; LDS-lower concentration double spraying; HSS - higher concentration single spraying; HDS-higher concentration double spraying. Means followed by different small letters are significantly different at $p<0.05$ (effect of biostimulant treatment). Means, followed by different big letters are significantly different at $p<0.05$ (effect of season). 
The complex assessment of the effect of the biostimulants differing in composition on the content of lignin in bean seeds demonstrated a higher efficacy of the Kelpak SL preparation. In addition, higher lignin contents were achieved in seeds in 2016 compared to the other study years.

Hemicellulose (HCEL) content of bean seeds was determined from the difference between contents of the neutral-detergent fiber (NDF) and acid-detergent fiber (ADF) fractions. The application of Kelpak SL biostimulant was observed to increase HCEL content of the seeds compared to the non-treated samples (average 2016-2018) (Figure 4). A significant increase in HCEL in 2016 and 2018 years content was determined after double application of this preparation in its higher concentration. In the 2017 year, the highest HCEL level in seeds was found after single application of this preparation in its lower concentration.

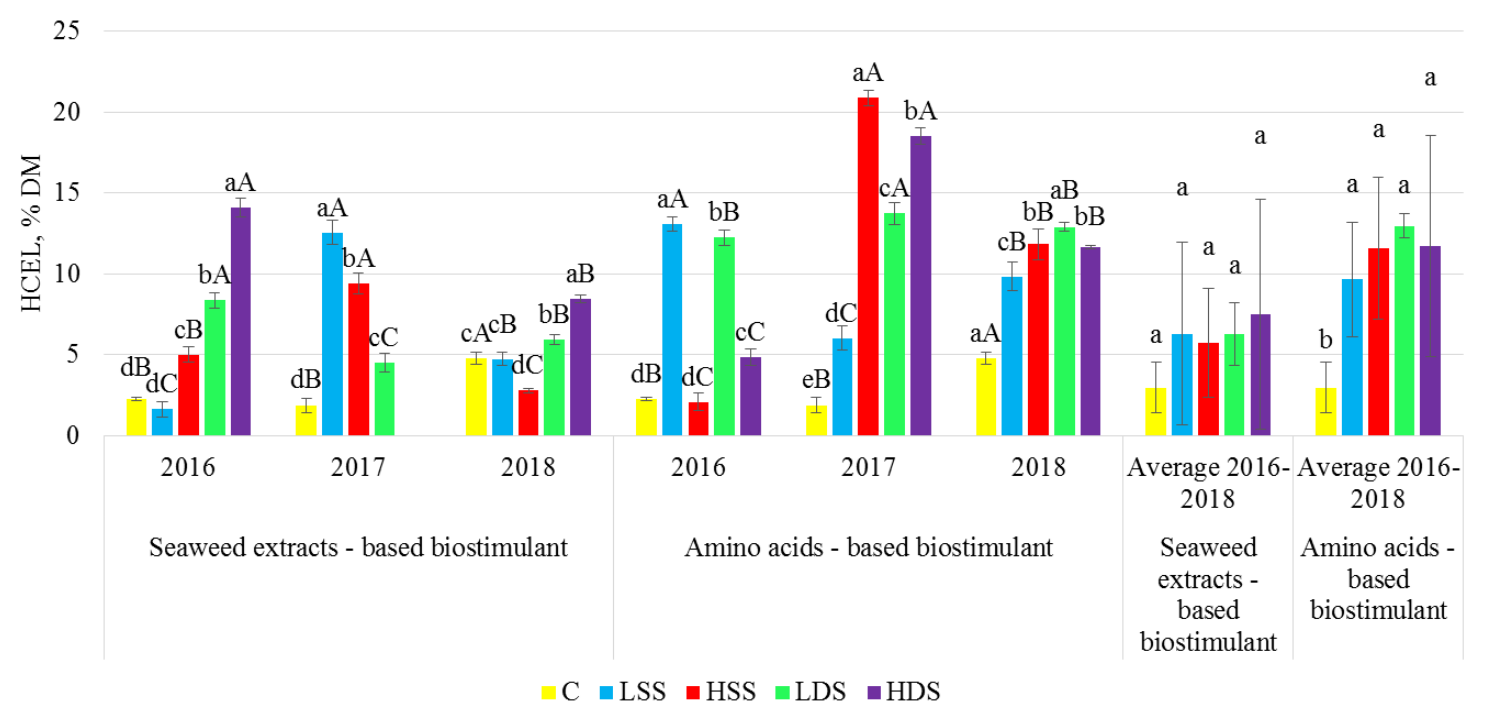

Figure 4. Effect of biostimulants treatment on the hemicellulose (HCEL) content in common bean seeds. Abbreviations: C - control; LSS-lower concentration single spraying; LDS-lower concentration double spraying; HSS—-higher concentration single spraying; HDS-higher concentration double spraying. Means followed by different small letters are significantly different at $p<0.05$ (effect of biostimulant treatment). Means, followed by different big letters are significantly different at $p<0.05$ (effect of season).

However, after the application of the Terra Sorb Complex biostimulant, high variability in the content of hemicellulose in seeds was observed. Plant treatment with Terra Sorb Complex biostimulant in 2016 year in the form of a single spraying in its higher concentration contributed to hemicellulose content decrease compared to the control seeds. In the other combinations, HCEL content was observed to increase, compared to the control. The highest content of HCEL was noted in 2017, after single plant treatment with Terra Sorb Complex in higher concentration. In the first and third growing season, the highest increase was also noted but after respectively single and double plant treatment with this biostimulant in its lower concentration.

Statistical analysis of the three-year averages, indicate significant differences in ADL content in seeds plant sprayed with Terra Sorb Complex compared to the control combination (Figure 4).

The analysis of the three-year averages shows the use of the biostimulant containing free amino acids decreased cellulose content of the seeds, regardless of the number of its applications and its concentration (Figure 5). The greatest decrease was demonstrated in each year of the experiment, after single spraying of plants with $0.5 \%$ Terra Sorb Complex (HSS). On the other hand the obtained results shows that in some combinations was noted the increase of CEL content. In 2016, the highest level of CEL was observed in seeds after single plant treatment by this biostimulant in its lower concentration. Whereas the similar tendency was demonstrated in 2017 and 2018 but after different 
plant treatments. In this case the highest increase of cellulose was noted after double plant spraying with Terra Sorb Complex in its higher concentration.

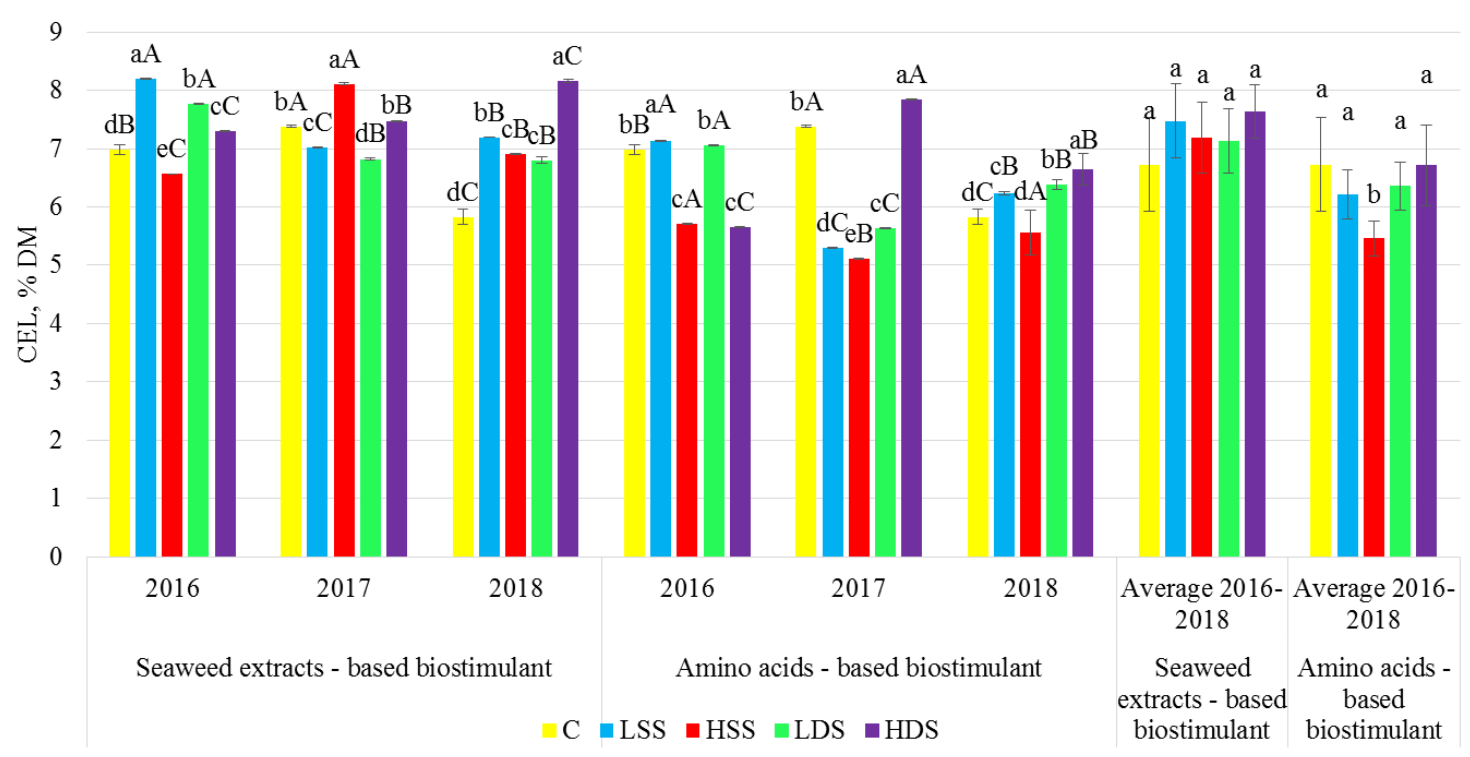

Figure 5. Effect of biostimulants treatment on the cellulose (CEL) content in common bean seeds. Abbreviations: C-control; LSS-lower concentration single spraying; LDS-lower concentration double spraying; HSS-higher concentration single spraying; HDS-higher concentration double spraying. Means followed by different small letters are significantly different at $p<0.05$ (effect of biostimulant treatment). Means, followed by different big letters are significantly different at $p<0.05$ (effect of season).

In contrast, plant treatment with Kelpak SL contributed generally to an increase in cellulose content of the seeds (average 2016-2018). However, CEL content decreased in three combinations: in 2016 for HSS and in 2017 for LSS and LDS. The analysis of the average results shows that the increase was statistically insignificant compared to the control seeds (Figure 5). In 2016 and 2017, the highest increase of CEL in seeds was contributed to the single plant spraying with respectively lower and higher concentration of Kelpak SL. In the third growing season, after double plant treatment with 1\% biostimulant the highest level of cellulose was noted.

\section{Discussion}

Considering the fact that plants are exposed to a variety of abiotic and biotic stresses that significantly reduce both the productivity and the quality of crops, the use of biostimulants has been proposed as one of the practical strategies in the agroecological crop management. The goal of such agroeconomic treatment is primarily to increase crop yield, while reducing production costs and increasing the efficiency of inputs. At the same time, the implementation of the strategies involving the use of natural preparations as plant growth promoters does not upset to environmental homeostasis [45], which in turn results in the reduced use of chemical fertilizers and by this means facilitates environment protection $[46,47]$. Results of the field experiment presented in this paper demonstrate that the use of Terra Sorb Complex and Kelpak SL biostimulants in bean cultivation may ensure higher plant tolerance to stress factors due to their multi-faceted action at both the biochemical and physiological level. In particular, study results prove the significant biostimulating effect on a few variables tested, including biometric traits, yield, as well as the nutraceutical potential of seeds. In the case of both biostimulants tested, various responses of plants were observed compared to the control combinations. Therefore, results obtained in the study confirm biostimulants' potency to increase crop effectiveness. 
It needs to be emphasized, however, that the biological effects exerted by their active compounds are distinctly different from these evoked by conventional fertilizers [16].

Our research confirmed results of many works that biostimulants properly applied in crops sensitive to stress would increase their yield compared to control treatment. We have also shown that biostimulants improve the structural elements of yield. However, the most exciting element of our research were the results concerning dietary fiber content in bean seeds harvested from crops treated with biostimulants, which showed changes contents of individual fiber fractions. When planning the research, our priority was not to determine the total content of dietary fiber in the seed yield produced, but above all, to determine its fractional composition because individual fiber fractions exert a variety of effects in the human body. In recent years, a significant deficiency of dietary fiber in the people diet has become visible, which mainly applies to developed countries [48]. The interest in food fiber has been increasing continuously since the mid-1960s. It was shown that individual components of the dietary fiber bind a number of substances, including cholesterol and stomach acids. Celluloses and lignin have a high metal binding capacity [49-51]. On the other hand, the NDF and ADF fractions act at the physiological level, improving digestibility, mineral availability, and additionally influencing a number of nutrient interactions [52].

The properties of hemicellulose can also play an important role in human physiology. This fiber fraction is significantly degraded in the colon and increases stool production. However, its most important function is its ability to bind ions and retain water [53].

The beneficial effect of the fiber fraction was indicated in studies by Hillman et al., who showed that dietary supplementation with maximum tolerated amounts of pectin, cellulose, or lignin is associated with significant changes in serum cholesterol levels in healthy people [54].

That is why, in our research, we presented the contents of NDF, ADF, ADL, HCEL, and CEL fractions. The major fraction turned out to be the neutral-detergent fiber (NDF), which is the sum of hemicellulose, cellulose, and lignin. The second fraction in terms of the content in seeds was the acid-detergent fiber (ADF), which is the sum of lignin and cellulose. Bean seeds, derived from crops treated with biostimulants, had higher levels of both mentioned fractions compared to the control samples, especially after double plant treatment with tested biostimulants. Unfortunately, the available literature on the use of biostimulants lacks information about whether and how their application affects the crop's fiber content. In turn, the research results presented by Godlewska and Ciepiela [55] indicate that tested grass species treatment with the Kelpak biostimulant led to a reduction in their NDF and ADF fiber fraction content compared to the control. However, these authors emphasize the sparsity of relevant literature available, which made a discussion on this topic impossible. Our study's results were inconsistent with findings reported by Godlewska and Ciepiela [55], as we have demonstrated in the most of tested combinations an increase in dietary fiber fraction content upon the application of biostimulants. Additionally, based on the average results, we have shown changes in hemicellulose content. This could be because the application of biostimulants based on amino acids and seaweeds stimulates the primary and secondary metabolism in plants by improving the absorption and assimilation of nutrients. As a result, the synthesis and accumulation of phytochemicals are promoted as well [26,56-63]. An increase in not only crop productivity but also in contents of individual fiber fractions in the crop induced by such biostimulants may be associated with several direct and indirect interactive mechanisms, including the stimulation of enzymatic activities related to carbon and nitrogen metabolism, Krebs cycle, and glycolysis, and with the induction of the hormone-like activity [64-67]. These statements are reflected in the research of Hammad and Ali [68]. They have emphasized that the use of amino acid-containing biostimulants is extremely beneficial in plant cultivation because these compounds participate in the biosynthesis of many different non-protein nitrogenous compounds. In addition, the biostimulants are a rich natural source of many growth-promoting substances, including cytokinins, gibberellins, auxins, and many nutrients including carbohydrates and nucleic acids [69]. El-Nabarawy [70] has also emphasized the importance and role of bioactive compounds of biostimulants that are involved in enzymatic processes, 
being of great importance for the synthesis of many other compounds. In addition, Abbas [71] has mentioned that the positive response of plants to the application of biostimulants can be attributed to the regulation of phytohormone activity [68]. It should also be pinpointed that the induction of fiber synthesis and differentiation into individual fractions in plants is controlled by plant hormones, including auxin (produced in the leaves), as well as gibberellin and cytokinin (produced in the roots) [72,73]. Increased contents of particular fiber fractions in bean seeds may be due to the action of auxins and gibberellins, which control the formation and structure of lignins in the cell walls [74]. Both these phytohormones are considered specific signaling compounds, which induce the process of fiber synthesis and accumulation in various components of plant cells and tissues [75,76].

The observed changes in bean seeds' fiber content may be due to the biologically active substances they contain. Biostimulants' application could have contributed to the activation of precursors of active gibberellin compounds, affecting the growth and development processes throughout the plant's life cycle $[77,78]$. Therefore, the use of biostimulants, rich in active compounds or activating compounds, makes plants respond to this agronomic practice with accelerated and increased growth, and enhanced fiber accumulation [76]. This has been evidenced in scientific research [79]. The authors emphasize that biostimulants influence many metabolic pathways at the molecular level, including the biosynthesis pathway of gibberellins responsible for fiber synthesis and regulated mainly by three 2-oxoglutarate-dependent dioxygenases, i.e., GA 20 oxidase, GA 3 oxidase, and GA 2 oxidase [80,81]. The first two enzymes catalyze the last two stages of the synthesis of bioactive gibberellins, while the third enzyme converts bioactive gibberellins and their precursors into inactive 2-hydroxylated forms. This proves that both the increase in GA20 oxidase regulation and the suppression of GA2 oxidase significantly determine the increase in endogenous levels of bioactive gibberellins, leading to enhanced synthesis and increased content of fiber in plant cell walls [76,82-86]. Study results reported by Bai et al. [79] also showed that the enhanced gibberellin production promoted sucrose synthase expression and secondary cell wall deposition. Therefore, their study proves that gibberellins in biostimulants may modify carbon division into cellulose synthesis and the secondary cell wall by regulating sucrose synthase expression.

Many studies have also indicated that the use of biostimulants based on free amino acids and seaweed extracts modifies the metabolic pathway of phenolic acid synthesis, which affects the accumulation of individual fiber fractions. This is because phenolic compounds of plant cell walls protect cellulose fiber in the plant cell wall, preventing its chemical and biological degradation [87]. As mentioned earlier, biostimulants affect the phenylpropanoid pathway associated with the biosynthesis of many different products, including lignins and other related components, being constituents of cell walls in different types of cells and tissues $[88,89]$. Cinnamaldehyde has been recognized as a key enzyme in the phenylpropanoid biosynthesis pathway because it is involved in the final stage of biosynthesis of monolignols [89,90], which are precursors of appropriate units such as p-hydroxyphenyl units that are incorporated into the lignin polymer [91]. The issue of regulating the biosynthesis of phenolic compounds and their effect on fiber content has been addressed in Moghaddam's research [92]. Based on genetic analysis, this author showed the presence of candidate genes that can pave the way for precise bean cultivation in the future, based on the relationship between the content of polyphenols and fiber in seeds. The main conclusion of that study was the interaction between fiber fractions and polyphenolic compounds, which is later translated into physiological and health benefits from consuming a food product [92].

However, the insights from many studies presented in the discussion should be summarized appropriately. So far, these are primarily assumptions about the synthesis of individual fiber fractions in the yield of crops treated with biostimulants. Many of our previous research, addressing the use of various types of biostimulants in bean and soybean crops, indeed indicate that these preparations do modify the synthesis of fiber fractions in seeds $[2,5,19,93,94]$. However, despite research results and the widely presented discussion, there is still no conclusive evidence how the active substances of biostimulants modify individual metabolic pathways in plants. Many efforts have been made to 
investigate the molecular basis of fiber synthesis and accumulation in plants. Many cDNAs have been isolated from cotton, and some have been functionally characterized [95-99]. A large number of recorded cotton sequence markers have been characterized at the transcription level $[100,101]$. However, comprehensive studies have shown that few genes are directly related to fiber yield and quantity and that the underlying genetic mechanisms of fiber synthesis are still mostly unknown [84].

\section{Conclusions}

Nevertheless, despite the small amount of data about biostimulants' mechanisms, our research has clearly demonstrated that their application in bean cultivation had a positive effect on the yield and structural elements of the yield of the tested plant. The type of biostimulant, number of its applications, and its concentration modified the biometric traits and crop productivity of bean seeds. Positive effect was noted of the double application of seaweed extracts-based product (Kelpak SL) in its higher concentration on bean seed yield. The use of biostimulants containing natural active compounds represents a sustainable and environmentally friendly agronomic practice.

Based on the obtained results from the three years field experiment, it was found that the tested biostimulants changed the fiber fractions of bean seeds. This increase of NDF, ADF, ADL, CEL, and HCEL was noted after double plant treatment with Kelpak SL (seaweed extracts-based product) but there were no significant differences in fiber fractions content between control samples. The level of these bioactive compounds was additionally determined by weather conditions occurring in a given growing season. Therefore, only the analysis of the results from individual years of the experiment showed significant differences and allowed to indicate the relationship. The ADF content in seeds was the highest after double plant treatment with Kelpak SL. While the increased concentration of NDF resulted from double spraying with lower concentration of this biostimulant. The increase in the ADL, HCEL, and CEL content of bean seeds represented plant response to the double application of this biostimulant in the higher concentration.

An opposite observation was made after application of amino acids-based product (Terra Sorb Complex). The analysis of the average results showed significant differences between the content of $\mathrm{ADF}, \mathrm{ADL}$, and CEL in seeds. Additionally, observations from individual growing seasons indicated that the use of Terra Sorb Complex caused an increase in the acid-detergent fiber, neutral-detergent fiber, lignin, and hemicellulose contents in bean seeds as an effect of double plant treatment with this biostimulant in lower concentration. It turned out to be troublesome to indicate the dependence of the cellulose content on the number of applications and the concentration of the biostimulant. In this case, the results noted in 2017 and 2018 showed that the double foliar application of Terra Sorb Complex in higher concentration, during common bean growing season caused increase in cellulose (CEL) content in its seeds.

However, it is also important to emphasize the need to continually develop and expand knowledge about the mechanisms of their action. The presented research results indicate not only a significant increase in bean seed yield, but also a change in the contents of individual fiber fractions in seeds compared to the control samples. On average, a better effect was observed when using the Kelpak SL biostimulant. Considering the biostimulant application method, it was found that they should be administered in the form of double spraying with solutions having a higher concentration. This study's results may also be a guide for food technologists and nutritionists and prove helpful in promoting plant products containing fiber as they indicate the benefits resulting from the use of biostimulants like, e.g., the increased contents of individual fiber fractions in seeds. This aspect is of great importance for consumers because the implementation of this agronomic practice offers them food with an increased nutraceutical potential.

Author Contributions: A.S., S.K., and P.F. conceived and designed the research. A.S., S.K., and K.T., performed the experiments. A.S., S.K., K.T., and P.F. prepared the materials. A.S., K.T., S.K., and P.F. analyzed the data. K.T., A.S., S.K., and P.F. wrote the paper P.F., A.S., S.K., and K.T. revised the manuscript. All authors have read and agreed to the published version of the manuscript. 
Funding: This research received no external funding.

Conflicts of Interest: The authors declare no conflict of interest.

\section{References}

1. Carvalho, S.; Vasconcelos, M.W. Producing more with less: Strategies and novel technologies for plant-based food biofortification. Food Res. Int. 2013, 54, 961-971. [CrossRef]

2. Szparaga, A. Wybrane Właściwości Fizyczne, Mechaniczne, Chemiczne i Plon Nasion Fasoli Zwykłej (Phaseolus vulgaris L.) w Zależności od Metody Aplikacji Biostymulatorów; Polskie Towarzystwo Inżynierii Rolniczej: Kraków, Poland, 2019.

3. Szparaga, A.; Kocira, S. Generalized logistic functions in modelling emergence of Brassica napus L. PLoS ONE 2018, 13, e0201980. [CrossRef] [PubMed]

4. Kocira, S.; Hara, P.; Szparaga, A.; Czerwińska, E.; Beloev, H.; Findura, P.; Bajus, P. Evaluation of the Effectiveness of the Use of Biopreparations as Seed Dressings. Agriculture 2020, 10, 90. [CrossRef]

5. Dymkowska-Malesa, M.; Szparaga, A.; Czerwińska, E. Evaluation of polychlorinated biphenyls content in chosen vegetables from Warmia and Mazury region. Rocz. Ochr. Srodowiska 2014, 16, 290-299.

6. Eckardt, N.A.; Cominelli, E.; Galbiati, M.; Tonelli, C. The future of science: Food and water for life. Plant Cell 2009, 21, 368-372. [CrossRef]

7. Rajabi Hamedani, S.; Rouphael, Y.; Colla, G.; Colantoni, A.; Cardarelli, M. Biostimulants as a Tool for Improving Environmental Sustainability of Greenhouse Vegetable Crops. Sustainability 2020, 12, 5101. [CrossRef]

8. Kyriacou, M.C.; Rouphael, Y. Towards a new definition of quality for fresh fruits and vegetables. Sci. Hortic. 2018, 234, 463-469. [CrossRef]

9. Regulation (EU) 2019/1009 of the European Parliament and of the Council of 5 June 2019 Laying Down Rules on the Making Available on the Market of EU Fertilising Products. Available online: https:/eur-lex.europa. eu/legal-content/EN/TXT/?uri=CELEX\%3A32019R1009 (accessed on 24 June 2020).

10. Godlewska, A.; Ciepiela, G.A. Yield Performance and Content of Selected Organic Compounds in Trifolium pratense Treated with Various Biostimulants against the Background of Nitrogen Fertilisation. Legume Res. 2020, LR-522. [CrossRef]

11. Rouphael, Y.; Colla, G. Editorial: Biostimulants in Agriculture. Front. Plant Sci. 2020, 11, 40. [CrossRef]

12. Kumar, H.D.; Aloke, P. Role of Biostimulant Formulations in Crop Production: An Overview. Int. J. Appl. Res. Vet. M 2020, 8, 38-46.

13. Chiaiese, P.; Corrado, G.; Colla, G.; Kyriacou, M.C.; Rouphael, Y. Renewable Sources of Plant Biostimulation: Microalgae as a Sustainable Means to Improve Crop Performance. Front. Plant Sci. 2018, 9, 1782. [CrossRef] [PubMed]

14. Colla, G.; Rouphael, Y. Microalgae: New Source of Plant Biostimulants. Agronomy 2020, 10, 1240. [CrossRef]

15. Norrie, J.; Keathley, J.P. Benefits of Ascophyllum nodosum marine-plant extract applications to 'Thompson seedless' grape production. Acta Hortic. 2006, 727, 243-247. [CrossRef]

16. Sharma, H.S.S.; Fleming, C.; Selby, C.; Rao, J.R.; Martin, T. Plant biostimulants: A review on the processing of macroalgae and use of extracts for crop management to reduce abiotic and biotic stresses. J. Appl. Phycol. 2014, 26, 465-490. [CrossRef]

17. Kocira, S.; Szparaga, A.; Kuboń, M.; Czerwińska, E.; Piskier, T. Morphological and Biochemical Responses of Glycine max (L.) Merr. to the Use of Seaweed Extract. Agronomy 2019, 9, 93. [CrossRef]

18. Kocira, S.; Kocira, A.; Kornas, R.; Koszel, M.; Szmigielski, M.; Krajewska, M.; Szparaga, A.; Krzysiak, Z. Effects of seaweed extract on yield and protein content of two common bean (Phaseolus vulgaris L.) cultivars. Legume Res. 2018, 41, 589-593. [CrossRef]

19. Michałek, W.; Kocira, A.; Findura, P.; Szparaga, A.; Kocira, S. The Influence of Biostimulant Asahi SL on the Photosynthetic Activity of Selected Cultivars of Phaseolus vulgaris L. Rocz. Ochr. Sr. 2018, 20, 1286-1301.

20. Hamza, B.; Suggars, A. Biostimulants: Myths and realities. TurfGrass Trends 2001, 10, 6-10.

21. Ertani, A.; Pizzeghelio, D.; Altissimo, A.; Nardi, S. Use of meat hydrolyzate derived from tanning residues as plant biostimulant for hydroponically grown maize. J. Plant Nutr. Soil Sci. 2013, 176, 287-295. [CrossRef]

22. Ashraf, M.; Foolad, M.R. Roles of glycine betaine and proline in improving plant abiotic stress resistance. Environ. Exp. Bot. 2007, 59, 206-216. [CrossRef] 
23. Kauffman, G.L., III; Kneival, D.P.; Watschke, T.L. Effects of biostimulant on the heat tolerance associated with photosynthetic capacity, membrane thermostability, and polphenol production of perennial ryegrass. Crop Sci. 2007, 47, 261-267. [CrossRef]

24. Chen, T.H.; Murata, N. Glycinebetaine: An effective protectant against abiotic stress in plants. Trends Plant Sci. 2008, 13, 499-505. [CrossRef] [PubMed]

25. Apone, F.; Tito, A.; Carola, A.; Arciello, S.; Tortora, A.; Filippini, L. A mixture of peptides and sugars derived from plant cell walls increases plant defense responses to stress and attenuates ageing-associated molecular changes in cultured skin cells. J. Biotechnol. 2010, 145, 367-376. [CrossRef] [PubMed]

26. Ertani, A.; Schiavon, M.; Muscolo, A.; Nardi, S. Alfalfa plant-derived biostimulant stimulate short-term growth of salt stressed Zea mays L. plants. Plant Soil 2013, 364, 145-158. [CrossRef]

27. Kocira, S.; Szparaga, A.; Kocira, A.; Czerwińska, E.; Wójtowicz, A.; Bronowicka-Mielniczuk, U.; Koszel, M.; Findura, P. Modeling biometric traits, yield and nutritional and antioxidant properties of seeds of three soybean cultivars through the application of biostimulant containing seaweed and amino acids. Front. Plant Sci. 2018, 9, 388. [CrossRef]

28. Kocira, S.; Kocira, A.; Szmigielski, M.; Piecak, A.; Sagan, A.; Malaga-Toboła, U. Effect of an amino acids-containing biostimulator on common bean crop. Przem. Chem. 2015, 94, 1732-1736. [CrossRef]

29. Kapusta, F. Legumes as protein source for humans and animals. Int. J. Eng. Sci. Technol. 2019, 1, 16-32.

30. Ulloa, J.A.; Rosas, U.P.; Ramírez, R.J.C.; Rangel, U.B.E. El frijol (Phaseolus vulgaris): Su importancia nutricional y como fuente de fitoquímicos. Rev. Fuente 2011, 3, 5-9.

31. Suárez-Martínez, S.E.; Ferriz-Martínez, R.A.; Campos-Vega, R.; Elton-Puente, J.E.; de la Torre Carbot, K.; García-Gasca, T. Bean seeds: Leading nutraceutical source for human health. CyTA-J. Food. 2016, 14, 131-137. [CrossRef]

32. Los, F.G.B.; Zielinski, A.A.F.; Wojeicchowski, J.P.; Nogueira, A.; Demiate, I.M. Beans (Phaseolus vulgaris L.): Whole seeds with complex chemical composition. Curr. Opin. Food Sci. 2018, 19, 63-71. [CrossRef]

33. Chávez-Mendoza, C.; Sánchez, E. Bioactive Compounds from Mexican Varieties of the Common Bean (Phaseolus vulgaris): Implications for Health. Molecules 2017, 22, 1360. [CrossRef] [PubMed]

34. Tosh, S.M.; Yada, S. Dietary fibers in pulse seeds and fractions: Characterization, functional attributes, and applications. Food Res. Int. 2010, 43, 450-460. [CrossRef]

35. Dueñas, M.; Fernández, D.; Hernández, T.; Estrella, I.; Muñoz, R. Bioactive phenolic compounds of cowpeas (Vigna sinensis L). Modifications by fermentation with natural microflora and with Lactobacillus plantarum ATCC 14917. J. Sci. Food Agric. 2005, 85, 297-304. [CrossRef]

36. Oomah, B.D.; Cardador-Martínez, A.; Loarca-Piña, G. Phenolics and antioxidative activities in common beans (Phaseolus vulgaris L). J. Sci. Food Agric. 2005, 85, 935-942. [CrossRef]

37. Rocha-Guzman, N.E.; Gallegos-Infante, J.A.; Gonzalez-Laredo, R.F.; Cardoza-Cervantes, V.; Reynoso-Camacho, R.; Ramos-Gomez, M.; Garcia-Gasca, T.; De Anda Salazar, A. Evaluation of culinary quality and antioxidant capacity for Mexican common beans (Phaseolus vulgaris L.) canned in pilot plant. Int. Food Res. J. 2013, 20, 1087-1093.

38. Moreno-Franco, B.; León-Latre, M.; Andrés-Esteban, E.M.; Ordovás, J.M.; Casasnovas, J.A.; Peñalvo, J.L. Soluble and insoluble dietary fibre intake and risk factors for cvd and metabolic syndrome in middle-aged adults: The AWHS cohort. Atherosclerosis 2014, 235, e279-e280. [CrossRef]

39. Guzmán, M.S.H.; Gallegos, J.A.A.; Muñoz, M.D.L.Á.Á.; Delgado, S.G.; Piña, G.L. Calidad alimentariay potencial nutracéutico del frijol (Phaseolus vulgaris L.) [Food quality and nutraceutical potential of common bean (Phaseolus vulgaris L.)]. Agric. Téc. México 2002, 28, 159-173.

40. Karr-Lilienthala, L.K.; Kadzereb, C.T.; Grieshopc, C.M.; Fahey, G.C., Jr. Chemical and nutritional properties of soybean carbohydrates as related to nonruminants: A review. Livest. Prod. Sci. 2005, 97, 1-12. [CrossRef]

41. Joubert, J.M.; Lefranc, G. Seaweed biostimulants in agriculture: Recent studies on mode of action two types of products from alga: Growth and nutrition stimulants and stimulants of plant Demence reactions. In Proceedings of the Biostimulators in Modern Agriculture, Warsaw, Poland, 7-8 February 2008.

42. Szparaga, A.; Kuboń, M.; Kocira, S.; Czerwińska, E.; Pawłowska, A.; Hara, P. Towards Sustainable Agriculture-Agronomic and Economic Effects of Biostimulant Use in Common Bean Cultivation. Sustainability 2019, 11, 4575. [CrossRef]

43. Kocira, S. Effect of amino acid biostimulant on the yield and nutraceutical potential of soybean. Chil. J. Agric. Res. 2019, 79, 17-25. [CrossRef] 
44. Van Soest, P.J.; Robertson, J.B.; Lewis, B.A. Methods for Dietary Fiber, Neutral Detergent Fiber, and Nonstarch Polysaccharides in Relation to Animal Nutrition. J. Dairy Sci. 1991, 74, 3583-3597. [CrossRef]

45. Bettoni, M.M.; Mogor, A.F.; Pauletti, V.; Goicoechea, N.; Aranjuelo, I.; Garmendia, I. Nutritional quality and yield of onion as affected by different application methods and doses of humic substances. J. Food Comp. Anal. 2016, 51, 37-44. [CrossRef]

46. Shahabivand, S.; Padash, A.; Aghaee, A.; Nasiri, Y.; Rezaei, P.F. Plant biostimulants (Funneliformis mosseae and humic substances) rather than chemical fertilizer improved biochemical responses in peppermint. Iran. J. Plant Physiol. 2018, 8, 2333-2344.

47. Lötze, E.; Hoffman, E.W. Nutrient composition and content of various biological active compounds of three South African-based commercial seaweed biostimulants. J. Appl. Phycol. 2016, 28, 1379-1386. [CrossRef]

48. Winiarska-Mieczan, A.; Siłtys, R. Evaluation of the content of crude fibre and its fractionsin cereal products. Bromat. Chem. Toksykol. 2009, 4, 1083-1088.

49. Jenkins, D.J.A.; Kendall, C.W.C.; Ransom, T.P.P. Dietary fiber, the evolution of the human diet and coronary heart disease. Nutr. Res. 1998, 18, 633-652. [CrossRef]

50. Jiménez-Escrig, A.; Sánchez-Muniz, F.J. Dietary fibre from Edible seaweeds: Chemical structure, physicochemical properties and effects on cholesterol metabolism. Nutr. Res. 2000, 20, 585-598. [CrossRef]

51. Nawirska-Olszanska, A.; Kucharska, A.Z.; Sokol-Letowska, A. Dietary fibre fractions in Cornelian cherry fruit [Cornus mas L.]. Zywn. Nauka Technol. Jakosc 2010, 2, 95-103. [CrossRef]

52. Baer, D.J.; Rumpler, W.V.; Miles, C.W.; Fahey, G.C., Jr. Dietary Fiber Decreases the Metabolizable Energy Content and Nutrient Digestibility of Mixed Diets Fed to Humans. J. Nutr. 1997, 4, 579-586. [CrossRef]

53. Segura, C.M.; Barbosa, M.E.; Matus, B.Á.; Cabrera, A.D.; Murguía, O.M.; Moguel, O.Y.; Betancur, A.D. Comparison of Chemical and Functional Properties of Stevia rebaudiana (Bertoni) Varieties Cultivated in Mexican Southeast. Am. J. Plant Sci. 2014, 5, 286-293. [CrossRef]

54. Hillman, L.C.; Peters, S.G.; Fisher, A. The Effects of the Fiber Components Pectin, Cellulose and Lignin on Serum Cholesterol Levels. Am. J. Clin. Nutr. 1985, 42, 207-213. [CrossRef] [PubMed]

55. Godlewska, A.; Ciepiela, G.A. The effect of growth regulator on dry matter yield and some chemical components in selected grass species and cultivars. J. Soil Sci. Plant Nutr. 2016, 62, 297-302. [CrossRef]

56. Botta, A. Enhancing plant tolerance to temperature stress with amino acids: An approach to their mode of action. Acta Hortic. 2013, 1009, 29-35. [CrossRef]

57. Colla, G.; Svecova, E.; Rouphael, Y.; Cardarelli, M.; Reynaud, H.; Canaguier, R.; Rouphael, Y. Effectiveness of a plant-derived protein hydrolysate to improve crop performances under different growing conditions. Acta Hortic. 2013, 1009, 175-179. [CrossRef]

58. Lucini, L.; Rouphael, Y.; Cardarelli, M.; Canaguier, R.; Kumar, P.; Colla, G. The effect of a plant-derived protein hydrolysate on metabolic profiling and crop performance of lettuce grown under saline conditions. Sci. Hortic. 2015, 182, 124-133. [CrossRef]

59. Xu, C.; Leskovar, D. Effects of A. nodosum seaweed extracts on spinach growth, physiology and nutrition valued under drought stress. Sci. Hortic. 2015, 183, 39-47. [CrossRef]

60. Rouphael, Y.; Colla, G.; Giordano, M.; El-Nakhel, C.; Kyriacou, M.C.; De Pascale, S. Foliar applications of a legume-derived protein hydrolysate elicit dose-dependent increases of growth, leaf mineral composition, yield and fruit quality in two greenhouse tomato cultivars. Sci. Hortic. 2017, 226, 353-360. [CrossRef]

61. Rouphael, Y.; De Micco, V.; Arena, C.; Raimondi, G.; Colla, G.; De Pascale, S. Effect of Ecklonia maxima seaweed extract on yield, mineral composition, gas exchange and leaf anatomy of zucchini squash grown under saline conditions. J. Appl. Phycol. 2017, 29, 459-470. [CrossRef]

62. Rouphael, Y.; Cardarelli, M.; Bonini, P.; Colla, G. Synergistic action of a microbial-based biostimulant and a plant derived-protein hydrolysate enhances lettuce tolerance to alkalinity and salinity. Front. Plant Sci. 2017, 8, 131. [CrossRef]

63. Di Stasio, E.; Rouphael, Y.; Colla, G.; Raimondi, G.; Giordano, M.; Pannico, A.; El-Nakhel, C.; De Pascale, S. The influence of Ecklonia maxima seaweed extract on growth, photosynthetic activity and mineral compositionof Brassica rapa L. subsp. sylvestris under nutrient stress conditions. Eur. J. Hortic. Sci. 2017, 82, 286-293. [CrossRef]

64. Colla, G.; Cardarelli, M.; Bonini, P.; Rouphael, Y. Foliar applications of protein hydrolysate, plant and seaweed extracts increase yield but differentially modulate fruit quality of greenhouse tomato. Hortic. Sci. 2017, 52, 1214-1220. [CrossRef] 
65. Colla, G.; Hoagland, L.; Ruzzi, M.; Cardarelli, M.; Bonini, P.; Canaguier, R.; Rouphael, Y. Biostimulant action of protein hydrolysates: Unraveling their effects on plant physiology and microbiome. Front. Plant Sci. 2017, 8, 2202. [CrossRef] [PubMed]

66. Colla, G.; Nardi, S.; Cardarelli, M.; Ertani, A.; Lucini, L.; Canaguiere, R.; Rouphael, J. Protein hydrolysates as biostimulants in horticulture. Hortic. Sci. 2015, 196, 28-38. [CrossRef]

67. Battacharyya, D.; Babgohari, M.Z.; Rathor, P.; Prithiviraj, B. Seaweed extracts as biostimulants in horticulture. Hortic. Sci. 2015, 196, 39-48. [CrossRef]

68. Salwa, A.R.; Hammada Osama, A.M. Ali Physiological and biochemical studies on drought tolerance of wheat plants by application of amino acids and yeast extract. Ann. Agric. Sci. 2014, 59, 133-145. [CrossRef]

69. Barnett, J.A.; Payne, R.W.; Yarrow, D. The Yeasts: Characteristics and Identification, 2nd ed.; Cambridge University Press: Cambridge, UK, 1990.

70. El-Nabarawy, M.A. Mitigation of dark induced senescence. 1-By some amino acids. Ann. Agric. Sci. Moshtohor Univ. 2001, 39, 225-232.

71. Abbas, S.M. The influence of biostimulants on the growth and on the biochemical composition of vicia faba CV. Giza 3 beans. Rom. Biotech. Lett. 2013, 18, 8061-8068.

72. Aloni, R.; Langhans, M.; Aloni, E.; Ullrich, C.I. Role of cytokinin in the regulation of root gravitropism. Planta 2004, 220, 177-182. [CrossRef]

73. Aloni, R.; Aloni, E.; Langhans, M.; Ullrich, C.I. Role of cytokinin and auxin in shaping root architecture: Regulating vascular differentiation, lateral root initiation, root apical dominance and root gravitropism. Ann. Bot. 2006, 97, 883-893. [CrossRef]

74. Aloni, R.; Tollier, M.T.; Monties, B. The role of auxin and gibberellin in controlling lignin formation in primary phloem fibers and in xylem of Coleus-blumei stems. Plant Physiol. 1990, 94, 1743-1747. [CrossRef]

75. Mauriat, M.; Moritz, T. Analyses of GA20ox- and GID1-over-expressing aspen suggest that gibberellins play two distinct roles in wood formation. Plant J. 2009, 58, 989-1003. [CrossRef] [PubMed]

76. Dayan, J.; Schwarzkopf, M.; Avni, A.; Aloni, R. Enhancing plant growth and fiber production by silencing GA 2-oxidase. Plant Biotechnol. J. 2010, 8, 425-435. [CrossRef] [PubMed]

77. Hooley, R. Gibberellins: Perception, transduction and responses. Plant Mol. Biol. 1994, 26, $1529-1555$. [CrossRef] [PubMed]

78. Kende, H.; Zeevaart, J. The five "classical" plant hormones. Plant Cell 1997, 9, 1197-1210. [CrossRef]

79. Bai, W.Q.; Xiao, Y.H.; Zhao, J.; Song, S.Q.; Hu, L.; Zeng, J.Y.; Li, X.B.; Hou, L.; Luo, M.; Li, D.M.; et al. Gibberellin overproduction promotes sucrose synthase expression and secondary cell wall deposition in cotton fibers. PLOS ONE 2014, 9, e96537. [CrossRef]

80. Hedden, P.; Thomas, S.G. Gibberellin biosynthesis and its regulation. Biochem. J. 2012, 444, 11-25. [CrossRef]

81. Yamaguchi, S. Gibberellin metabolism and its regulation. Annu. Rev. Plant Biol. 2008, 59, 225-251. [CrossRef]

82. Bhattacharya, A.; Ward, D.A.; Hedden, P.; Phillips, A.L.; Power, J.B.; Davey, M.R. Engineering gibberellin metabolism in Solanum nigrum L. by ectopic expression of gibberellin oxidase genes. Plant Cell 2012, 31, 945-953. [CrossRef]

83. Gou, J.; Ma, C.; Kadmiel, M.; Gai, Y.; Strauss, S.; Jiang, X.; Busov, V. Tissue-specific expression of Populus C19 GA 2-oxidases differentially regulate above- and below-ground biomass growth through control of bioactive GA concentrations. New Phytol. 2011, 192, 626-639. [CrossRef]

84. Xiao, Y.-H.; Li, D.-M.; Yin, M.-H.; Li, X.-B.; Zhang, M.; Wang, Y.-J.; Dong, J.; Zhao, J.; Luo, M.; Luo, X.-Y.; et al. Gibberellin 20- oxidase promotes initiation and elongation of cotton fibers by regulating gibberellin synthesis. J. Plant Physiol. 2010, 167, 829-837. [CrossRef]

85. Vidal, A.M.; Gisbert, C.; Talón, M.; Primo-Millo, E.; López-Díaz, I.; García-Martínez, J.L. The ectopic overexpression of a citrus gibberellin 20-oxidase enhances the non-13- hydroxylation pathway of gibberellin biosynthesis and induces an extremely elongated phenotype in tobacco. Physiol. Plant. 2001, 112, 251-260. [CrossRef] [PubMed]

86. Eriksson, M.E.; Israelsson, M.; Olsson, O.; Moritz, T. Increased gibberellins biosynthesis in transgenic trees promotes growth, biomass production and xylem fiber length. Nat. Biotechnol. 2000, 18, 784-788. [CrossRef] [PubMed]

87. Grabber, J.H.; Ralph, J.; Lapierre, C.; Barrière, Y. Genetic and molecular basis of grass cell-wall degradability. I. Lignin-cell wall matrix interactions. C. R. Biol. 2004, 327, 455-465. [CrossRef] [PubMed] 
88. Anterola, A.M.; Lewis, N.G. Trends in lignin modification: A comprehensive analysis of the effects of genetic manipulations/mutations on lignification and vascular integrity. Phytochemistry 2002, 61, 221-294. [CrossRef]

89. Boerjan, W.; Ralph, J.; Baucher, M. Lignin biosynthesis. Annu. Rev. Plant Biol. 2003, 54, 519-546. [CrossRef]

90. Goffner, D.; Joffroy, I.; Grima-Pettenati, J.; Halpin, C.; Knight, M.E.; Schuch, W.; Boudet, A.M. Purification and characterization of isoforms of cinnamyl alcohol dehydrogenase from Eucalyptus xylem. Planta 1992, 188, 48-53. [CrossRef]

91. Fan, L.; Shi, W.J.; Hu, W.R.; Hao, X.Y.; Wang, D.M.; Yuan, H.; Yan, H.Y. Molecular and biochemical evidence for phenylpropanoid synthesis and presence of wall-linked phenolics in cotton fibers. J. Integr. Plant Biol. 2009, 51, 626-637. [CrossRef]

92. Moghaddam, S.M.; Brick, M.A.; Echeverria, D.; Thompson, A.J.; Brick, L.A.; Lee, R.; Mamidi, S.; McClean, P.E. Genetic Architecture of Dietary Fiber and Oligosaccharide Content in a Middle American Panel of Edible Dry Bean. Plant Genome 2018, 11, 170074. [CrossRef]

93. Szparaga, A.; Kocira, S.; Kocira, A.; Czerwińska, E.; Świeca, M.; Lorencowicz, E.; Kornas, R.; Koszel, M.; Oniszczuk, T. Modification of growth, yield, and the nutraceutical and antioxidative potential of soybean through the use of synthetic biostimulants. Front. Plant Sci. 2018, 9, 1401. [CrossRef]

94. Kocira, S.; Szparaga, A.; Kocira, A.; Czerwińska, E.; Depo, K.; Erlichowska, B.; Deszcz, E. Effect of applying a biostimulant containing seaweed and amino acids on the content of fiber fractions in three soybean cultivars. Legume Res. 2019, 42, 341-347. [CrossRef]

95. Kim, H.; Triplet, B.A. Cotton fiber growth in planta and in vitro. Models for plant cell elongation and cell wall biogenesis. Plant Physiol. 2001, 127, 1361-1366. [CrossRef] [PubMed]

96. Li, X.-B.; Fan, X.-P.; Wang, X.-L.; Cai, L.; Yang, W.-C. The cotton ACTIN1 gene is functionally expressed in fibers and participates in fiber elongation. Plant Cell 2005, 17, 859-875. [CrossRef] [PubMed]

97. Pu, L.; Li, Q.; Fan, X.; Yang, W.; Xue, Y. The R2R3 MYB transcription factor GhMYB109 is required for cotton fiber development. Genetics 2008, 180, 811-820. [CrossRef]

98. Qin, Y.-M.; Hu, C.-Y.; Pang, Y.; Kastaniotis, A.J.; Hiltunen, J.K.; Zhu, Y.-X. Saturated very-long- chain fatty acids promote cotton fiber and Arabidopsis cell elongation by activating ethylene biosynthesis. Plant Cell 2007, 19, 3692-3704. [CrossRef] [PubMed]

99. Zhu, Y.-Q.; Xu, K.-X.; Luo, B.; Wang, J.-W.; Chen, X.-Y. An ATP-binding cassette transporter GhWBC1 from elongating cotton fibers. Plant Physiol. 2003, 133, 580-588. [CrossRef] [PubMed]

100. Shi, Y.-H.; Zhu, S.-W.; Mao, X.-Z.; Feng, J.-X.; Qin, Y.-M.; Zhang, L.; Cheng, J.; Wei, L.-P.; Wang, Z.-Y.; Zhu, Y.-X. Transcriptome profiling, molecular biological, and physiological studies reveal a major role for ethylene in cotton fiber cell elongation. Plant Cell 2006, 18, 651-664. [CrossRef] [PubMed]

101. Yang, S.S.; Cheung, F.; Lee, J.J.; Ha, M.; Wei, N.E.; Sze, S.-H.; Stelly, D.M.; Thaxton, P.; Triplett, B.; Town, C.D.; et al. Accumulation of genome- specific transcripts, transcription factors and phytohormonal regulators during early stages of fiber cell development in allotetraploid cotton. Plant J. 2006, 47, 761-775. [CrossRef] 